\title{
Economics and Nutrient Uptake by Blackgram as Influenced by Secondary Nutrients and Zinc Nutrition
}

\author{
E. Jeevana Lakshmi ${ }^{*}$, P.V. Ramesh Babu ${ }^{2}$, G. Prabhakara Reddy ${ }^{1}$ and P. Kavitha ${ }^{3}$ \\ ${ }^{1}$ Department of Agronomy, S.V. Agricultural College, Tirupati, India \\ ${ }^{2}$ Department of Agronomy, ${ }^{3}$ Department of Soil Science and Agricultural Chemistry, \\ Agricultural College, Mahanandi, India \\ *Corresponding author
}

\begin{abstract}
A B S T R A C T
Keywords

Calcium, Magnesium, Zinc, Foliar application,

Nutrient uptake and blackgram

Article Info

Accepted: 18 September 2018 Available Online: 10 October 2018

To study the effect of foliar sprays of secondary nutrients and zinc nutrition on nutrient uptake and economics of blackgram, a field experiment was conducted during rabi, 201617 on sandy loam soils of College Farm, Agricultural College, Mahanandi. The experiment comprised of eight treatments viz., control $\left(\mathrm{T}_{1}\right)$, RDF (20-50-0 kg N-P $\mathrm{O}_{5}-\mathrm{K}_{2} \mathrm{O}$ ha $\left.{ }^{-1}\right)\left(\mathrm{T}_{2}\right)$, $\mathrm{RDF}+$ foliar application of one per cent $\mathrm{CaNO}_{3}\left(\mathrm{~T}_{3}\right), \mathrm{RDF}+$ foliar application of one per cent $\mathrm{MgNO}_{3}\left(\mathrm{~T}_{4}\right), \mathrm{RDF}+$ foliar application of one per cent Sulphur $\left(\mathrm{T}_{5}\right), \mathrm{RDF}+$ foliar application of one per cent each of $\mathrm{CaNO}_{3}, \mathrm{MgNO}_{3}$ and Sulphur $\left(\mathrm{T}_{6}\right), \mathrm{RDF}+$ foliar application of $\mathrm{ZnSO}_{4} @ 0.2$ per cent $\left(\mathrm{T}_{7}\right), \mathrm{T}_{6}+$ foliar application of $\mathrm{ZnSO}_{4} @ 0.2$ per cent $\left(\mathrm{T}_{8}\right)$. As per the results, foliar spray of secondary nutrients $(\mathrm{Ca}, \mathrm{Mg}$ and Sulphur) and zinc at 25 and 45 DAS along with RDF $\left(\mathrm{T}_{8}\right)$ recorded the higher values of dry matter, seed yield, haulm yield and nutrient uptake (secondary and zinc) while control treatment recorded the lower values among the treatments tested.
\end{abstract}

\section{Introduction}

Pulses being the cheap source of protein ensure nutritional security in India and also play a vital role in restoring the soil nutrient status through biological nitrogen fixation acting as mini factories for improving soil health (Pooniya et al., 2015). They are cultivated on marginal and sub marginal soils under rainfed situations with marginal inputs. As pulses are legumes, nutrient management aspect is ignored in many situations. However, from the essentiality point of view, all the essential elements are crucial for plant growth
(Fageria et al., 2009). In post green revolution era due to intensification of agriculture, soil capacity to supply all the essential nutrients is declining. For producing one ton of biomass pulses generally remove $3-10 \mathrm{~kg}$ of $\mathrm{Ca}, 1-5 \mathrm{~kg}$ of $\mathrm{Mg}$ and 1-3 $\mathrm{kg} \mathrm{S}$ along with other major and minor elements (Choudhary et al., 2014).

Sulphur is the fourth essential and most deficient secondary nutrient in Indian soils. It is required nearly in equal quantities as that of $\mathrm{P}$ in legumes and it should not be over looked for attaining higher yields and quality produce (Singh, 2004). The most deficient 
micronutrient in Indian soils is zinc, making it mandatory to include in the nutrient management practices. Appropriate recommendations are needed because of increasing fertilizer costs and awareness of environmental problems. Soil application of nutrients is a common practice for all the major nutrients but, the secondary and micro nutrients are required in relatively smaller quantities than major nutrients. So foliar application may solve the purpose and reduce the impact on dynamic soil system. Foliar application targets the above ground parts where the nutrient is needed and rapid absorption is facilitated. It overcomes the losses such as fixation, leaching, volatilization and decomposition which occur through soil application. As the nutrient needed for foliar sprays is less it is economical in achieving high monetary returns than soil application.

\section{Materials and Methods}

A field experiment was conducted at College Farm, Agricultural College, Mahanandi, Andhra Pradesh during rabi, 2016-17. The texture of the soil was sandy loam, neutral in reaction, medium in organic carbon and nitrogen, high in phosphorus, potassium and sulphur, medium in calcium, low in magnesium and nearly medium in zinc. The experiment comprised of eight treatments viz., control $\left(\mathrm{T}_{1}\right)$, RDF (20-50-0 kg N-P $\mathrm{O}_{5}-\mathrm{K}_{2} \mathrm{O}$ $\left.\mathrm{ha}^{-1}\right)\left(\mathrm{T}_{2}\right), \mathrm{RDF}+$ foliar application of one per cent $\mathrm{CaNO}_{3}\left(\mathrm{~T}_{3}\right), \mathrm{RDF}+$ foliar application of one per cent $\mathrm{MgNO}_{3}\left(\mathrm{~T}_{4}\right), \mathrm{RDF}+$ foliar application of one per cent Sulphur $\left(\mathrm{T}_{5}\right)$, RDF + foliar application of one per cent each of $\mathrm{CaNO}_{3}, \mathrm{MgNO}_{3}$ and Sulphur $\left(\mathrm{T}_{6}\right), \mathrm{RDF}+$ foliar application of $\mathrm{ZnSO}_{4} @ 0.2$ per cent $\left(\mathrm{T}_{7}\right), \mathrm{T}_{6}+$ foliar application of $\mathrm{ZnSO}_{4} @ 0.2$ per cent $\left(T_{8}\right)$. The test variety was TBG-104. The trail was laid out in RBD replicated thrice. The foliar spray of nutrients was carried out at 25 and 45 DAS @ $5001 \mathrm{ha}^{-1}$. Five plants in each plot were marked separately for non-destructive sampling. Dry matter production per hectare was worked out by taking the oven dry weight of all the five plants drawn from the gross plot leaving the extreme border row and expressed as $\mathrm{kg} \mathrm{ha}^{-1}$. Later these samples were powdered for the chemical estimation.

Diacid digestion was done using $1 \mathrm{gm}$ of powered plant sample and $10 \mathrm{ml}$ of 10:4 mixture of nitric acid $\left(\mathrm{HNO}_{3}\right)$ and perchloric acid $\left(\mathrm{HClO}_{4}\right)$. Pre-digestion was carried out using $25 \mathrm{ml}$ of nitric acid per gram of plant sample to avoid explosion. The digested plant sample was diluted to a known volume (100 $\mathrm{ml}$ ) with double distilled water and filtered through Whatman No.1 filter paper. Aliquots of this diluted digest were used for the estimation of calcium, magnesium (EDTA titration method by Cheng and Bray, 1951), sulphur (turbidometric method by Tandon, 1998) and zinc (AAS) by adopting the standard procedures.

The uptake of calcium, magnesium and sulphur at 30 and 60 DAS by whole plant and at harvest by seed and haulm samples was calculated as follows.

Uptake of nutrient $\left(\mathrm{kg} \mathrm{ha}^{-1}\right)=$ Nutrient content (\%) / 100] X Dry matter yield $\left(\mathrm{kg} \mathrm{ha}^{-1}\right)$

The uptake of zinc at 30 and 60 DAS by whole plant and at harvest by seed and haulm samples was calculated as follows.

Uptake of nutrient $\left(\mathrm{g} \mathrm{ha}^{-1}\right)=[$ Nutrient content $(\mathrm{ppm}) / 1000$ ] X Dry matter yield $\left(\mathrm{kg} \mathrm{ha}^{-1}\right)$

The total cost of cultivation and gross returns of blackgram was calculated for all the treatments on the basis of inputs used and prevailing market price of the economic produce. Net returns were obtained by deducting the cost of cultivation of respective 
treatments from gross returns of the corresponding treatments. Benefit-cost ratio was worked out by dividing gross returns with corresponding cost of cultivation of the respective treatments.

Statistical significance was tested by ' $F$ ' value at 5 per cent level of probability and wherever the ' $F$ ' value was found significant, critical difference was worked out and the values were furnished.

\section{Results and Discussion}

Dry matter production, seed yield and haulm yield

The dry matter production seed yield and haulm yield of blackgram were increased significantly with $\mathrm{T}_{6}+$ foliar application of $\mathrm{ZnSO}_{4} @ 0.2$ per cent $\left(\mathrm{T}_{8}\right)$ treatment and the next best treatment was RDF + foliar application of one per cent each of $\mathrm{CaNO}_{3}$, $\mathrm{MgNO}_{3}$ and sulphur $\left(\mathrm{T}_{6}\right)$. The control $\left(\mathrm{T}_{1}\right)$ treatment recorded lower values of dry matter production and yields. With regard to individual secondary nutrients and zinc foliar sprays, RDF + foliar application of one per cent $\mathrm{MgNO}_{3}\left(\mathrm{~T}_{4}\right)$ treatment reported higher dry matter production, seed yield and haulm yield and was comparable to RDF + foliar application of one per cent $\mathrm{CaNO}_{3}\left(\mathrm{~T}_{3}\right)$ treatment (Table 1). While, $\mathrm{RDF}+$ foliar application of one per cent sulphur $\left(\mathrm{T}_{5}\right)$ and $\mathrm{RDF}+$ foliar application of $\mathrm{ZnSO}_{4} @ 0.2$ per cent $\left(\mathrm{T}_{7}\right)$ treatments did not record any significant increase in haulm yields over RDF treatment.

The adequate supply of the nutrients stimulated growth and accelerated metabolic activities like carbohydrate and nitrogen fixation in the combination treatments which contributed to the increased dry matter production and yields (Prasanna et al., 2013). The substantial increase in the growth of the plants leading to higher values of yield parameters might be the reason for higher seed yield in the combination treatments and the results were supported by Veerabhadrappa and Yeledhalli (2005a) and Zafar et al., (2014). In the nutrient combination, zinc might have played a considerable role in the development of functional floral tissues for normal flower and pod development (Hafeez et al., 2013) but the effect was unnoticeable on haulm yield in the present study. Among the individual secondary nutrient foliar sprays, magnesium nitrate was found to be encouraging in achieving higher dry matter and yields. Magnesium, due to its role in the formation of organic compounds and increasing plant metabolism (Howladar et al., 2014), calcium due to its role in regulating cellular functions and the structural support of the plant might have increased the haulm yields.

\section{Nutrient uptake of blackgram}

Foliar application of secondary nutrients and zinc have exerted a progressive and significant influence on the nutrient uptake of blackgram at 30,60 DAS and at harvest. There exist nutrient interactions in plant. The net influence of these interactions and processes produce the final yield from the crop (Fageria, 2001). Among all the treatments control $\left(T_{1}\right)$ treatment recorded the lower nutrient uptake values.

\section{Calcium}

As the dry matter increased from 30 days to harvest the uptake of calcium was also increased. The uptake of calcium in seed was lower as compared to haulm due to the reason that calcium is immobile in the plant system (Meena et al., 2007).

The treatment $\mathrm{T}_{6}+$ foliar application of $\mathrm{ZnSO}_{4}$ @ 0.2 per cent $\left(\mathrm{T}_{8}\right)$ recorded higher calcium uptake at all the stages and was comparable 
with $\mathrm{RDF}+$ foliar application of one per cent each of $\mathrm{CaNO}_{3}, \mathrm{MgNO}_{3}$ and sulphur $\left(\mathrm{T}_{6}\right)$ treatment at 30 DAS and at harvest by haulm. With respect to individual secondary nutrients and zinc foliar sprays, at all the stages of crop growth even in the haulm and seed, RDF + foliar application of one per cent $\mathrm{CaNO}_{3}\left(\mathrm{~T}_{3}\right)$ treatment showed greater calcium uptake and was comparable to RDF + foliar application of one per cent $\mathrm{MgNO}_{3}\left(\mathrm{~T}_{4}\right)$ treatment at 30 and 60 DAS (Table 2).

The calcium uptake varied interestingly at all the growth stages. The combined nutrient treatments recorded higher uptake of calcium and this might be due to increased dry matter production and calcium is one of the elements in the nutrient combination. With reference to individual secondary nutrients and zinc foliar sprays, though magnesium spray had higher dry matter accumulation calcium spray showed an increase in the uptake due to higher nutrient concentration in calcium spray. The binding strengths of calcium are much stronger than magnesium and they easily outcompete magnesium at the exchange sites thus, there existed an antagonism and this was the reason for lower calcium uptake with magnesium foliar spray. The zinc foliar spray also showed a decline in the calcium uptake due to its antagonism with calcium was reported by Ranade and Malvi (2011) and Prasad et al., (2016).

\section{Magnesium}

The magnesium uptake was in the treatment that received $\mathrm{T}_{6}+$ foliar application of $\mathrm{ZnSO}_{4}$ @ 0.2 per cent $\left(\mathrm{T}_{8}\right)$ and was equally effective with $\mathrm{RDF}+$ foliar application of one per cent each of $\mathrm{CaNO}_{3}, \mathrm{MgNO}_{3}$ and sulphur $\left(\mathrm{T}_{6}\right)$ treatment at 30 DAS and at harvest by both seed and haulm. The treatment $\mathrm{RDF}+$ foliar application of one per cent $\mathrm{MgNO}_{3}\left(\mathrm{~T}_{4}\right)$ was greater in recording the magnesium uptake among the individual secondary nutrients and zinc foliar sprays. This particular treatment was comparable to $T_{6}$ treatment at all the stages of crop growth and even at harvest (Table 3). On the other hand, RDF + foliar application of one per cent $\mathrm{CaNO}_{3}\left(\mathrm{~T}_{3}\right)$, RDF + foliar application of one per cent sulphur $\left(\mathrm{T}_{5}\right)$ and $\mathrm{RDF}+$ foliar application of $\mathrm{ZnSO}_{4} @$ 0.2 per cent $\left(\mathrm{T}_{7}\right)$ treatments not showed any significant increase and were on par with each other at 30 and 60 DAS.

Higher uptake of magnesium in the combination treatments was due to their higher dry matter accumulation and higher root activity for absorption of availability of nutrients even from the soil resulted in positive results with combination treatments. On the other hand synergism between nitrogen-magnesium (Ranade and Malvi, 2011) and magnesium-zinc might have contributed to the present results with combination treatments. Higher calcium concentration inhibits the uptake of magnesium due to decrease in the permeability of cells (Fageria, 2001) owing to this the uptake of magnesium in the calcium foliar spray decreased despite of higher dry matter accumulation. The positive results of magnesium foliar application on uptake of magnesium and zinc was reported by Rady and Osman (2010), Mobarak et al., (2013) and Howladar et al., (2014).

\section{Sulphur}

The sulphur uptake by seed was higher in pulses than in cereals due the need of producing seed for synthesis of sulphur containing amino acids in protein formation.

Among all the foliar spray treatments, $\mathrm{T}_{6}+$ foliar application of $\mathrm{ZnSO}_{4}$ @ 0.2 per cent $\left(\mathrm{T}_{8}\right)$ obtained higher sulphur uptake and was appreciably higher than RDF + foliar application of one per cent each of $\mathrm{CaNO}_{3}$, $\mathrm{MgNO}_{3}$ and sulphur $\left(\mathrm{T}_{6}\right)$ treatment (Table 4). 
Table.1 Dry matter production $\left(\mathrm{kg} \mathrm{ha}^{-1}\right)$, seed yield $\left(\mathrm{kg} \mathrm{ha}^{-1}\right)$ and haulm yield $\left(\mathrm{kg} \mathrm{ha}^{-1}\right)$ of blackgram as influenced by secondary nutrients and zinc nutrition

\begin{tabular}{|c|c|c|c|c|}
\hline \multirow[t]{2}{*}{ Treatments } & \multicolumn{2}{|c|}{$\begin{array}{l}\text { Dry matter production } \\
\qquad\left(\mathrm{kg} \mathrm{ha}^{-1}\right)\end{array}$} & \multirow[t]{2}{*}{$\begin{array}{l}\text { Seed yield } \\
\left(\mathrm{kg} \mathrm{ha}^{-1}\right)\end{array}$} & \multirow[t]{2}{*}{$\begin{array}{l}\text { Haulm yield } \\
\qquad\left(\mathrm{kg} \mathrm{ha}^{-1}\right)\end{array}$} \\
\hline & 30 DAS & 60 DAS & & \\
\hline $\mathrm{T}_{1}$ : Control & 285 & 1068 & 508 & 1210 \\
\hline $\mathrm{T}_{2}:$ Recommended dose of fertilizers (RDF) $\left(20-50-0 \mathrm{~kg} \mathrm{~N}, \mathrm{P}_{2} \mathrm{O}_{5}\right.$ and $\left.\mathrm{K}_{2} \mathrm{O} \mathrm{ha}^{-1}\right)$ & 312 & 1169 & 639 & 1336 \\
\hline $\mathrm{T}_{3}: \mathrm{RDF}+$ Foliar application of $1 \% \mathrm{CaNO}_{3}$ & 346 & 1565 & 1019 & 1776 \\
\hline $\mathrm{T}_{4}: \mathrm{RDF}+$ Foliar application of $1 \% \mathrm{MgNO}_{3}$ & 355 & 1691 & 1089 & 1798 \\
\hline $\mathrm{T}_{5}:$ RDF + Foliar application of $1 \%$ Sulphur & 319 & 1419 & 894 & 1492 \\
\hline $\mathrm{T}_{6}:$ RDF + Foliar application of $1 \%$ each of $\mathrm{CaNO}_{3}, \mathrm{MgNO}_{3}$ and Sulphur & 377 & 2011 & 1187 & 1906 \\
\hline $\mathrm{T}_{7}: \mathrm{RDF}+$ Foliar application of $\mathrm{ZnSO}_{4} @ 0.2 \%$ & 315 & 1227 & 782 & 1377 \\
\hline $\mathrm{T}_{8}: \mathrm{T}_{6}+$ Foliar application of $\mathrm{ZnSO}_{4} @ 0.2 \%$ & 414 & 2331 & 1284 & 2025 \\
\hline SEm \pm & 13 & 83 & 48 & 52 \\
\hline $\mathrm{CD}(\mathrm{P}=\mathbf{0 . 0 5})$ & 40 & 253 & 146 & 159 \\
\hline
\end{tabular}

Table. 2 Ca uptake $\left(\mathrm{kg} \mathrm{ha}^{-1}\right)$ by blackgram at different growth stages as influenced by secondary nutrients and zinc nutrition

\begin{tabular}{|c|c|c|c|c|}
\hline \multirow[t]{3}{*}{ Treatments } & \multicolumn{4}{|c|}{ Ca uptake $\left(\mathrm{kg} \mathrm{ha}^{-1}\right)$} \\
\hline & \multirow{2}{*}{30 DAS } & \multirow{2}{*}{60 DAS } & \multicolumn{2}{|c|}{ At harvest } \\
\hline & & & Haulm & Seed \\
\hline $\mathrm{T}_{1}$ : Control & 3.19 & 10.92 & 19.16 & 0.71 \\
\hline $\mathrm{T}_{3}: \mathrm{RDF}+$ Foliar application of $1 \% \mathrm{CaNO}_{3}$ & 5.07 & 20.07 & 33.52 & 2.35 \\
\hline $\mathrm{T}_{4}: \mathrm{RDF}+$ Foliar application of $1 \% \mathrm{MgNO}_{3}$ & 4.47 & 19.65 & 29.64 & 1.96 \\
\hline T7: RDF + Foliar application of $\mathrm{ZnSO}_{4} @ 0.2 \%$ & 3.95 & 13.90 & 22.64 & 1.39 \\
\hline $\mathrm{T}_{8}: \mathrm{T}_{6}+$ Foliar application of $\mathrm{ZnSO}_{4} @ 0.2 \%$ & 5.76 & 29.07 & 36.42 & 2.82 \\
\hline SEm \pm & 0.216 & 1.047 & 1.253 & 0.074 \\
\hline $\mathrm{CD}(\mathrm{P}=\mathbf{0 . 0 5})$ & 0.66 & 3.18 & 3.80 & 0.22 \\
\hline
\end{tabular}


Table.3 Mg uptake $\left(\mathrm{kg} \mathrm{ha}^{-1}\right)$ by blackgram at different growth stages as influenced by secondary nutrients and zinc nutrition

\begin{tabular}{|c|c|c|c|c|}
\hline \multirow[t]{3}{*}{ Treatments } & \multicolumn{4}{|c|}{ Mg uptake (kg ha $\left.{ }^{-1}\right)$} \\
\hline & \multirow[t]{2}{*}{30 DAS } & \multirow[t]{2}{*}{60 DAS } & \multicolumn{2}{|c|}{ At harvest } \\
\hline & & & Haulm & Seed \\
\hline $\mathrm{T}_{1}$ : Control & 2.56 & 6.49 & 7.12 & 0.80 \\
\hline $\mathrm{T}_{2}:$ Recommended dose of fertilizers (RDF) $\left(20-50-0 \mathrm{~kg} \mathrm{~N}, \mathrm{P}_{2} \mathrm{O}_{5}\right.$ and $\left.\mathrm{K}_{2} \mathrm{O} \mathrm{ha}^{-1}\right)$ & 2.89 & 7.39 & 8.29 & 1.16 \\
\hline $\mathrm{T}_{3}: \mathrm{RDF}+$ Foliar application of $1 \% \mathrm{CaNO}_{3}$ & 3.20 & 9.69 & 11.10 & 1.78 \\
\hline $\mathrm{T}_{4}: \mathrm{RDF}+$ Foliar application of $1 \% \mathrm{MgNO}_{3}$ & 3.66 & 12.88 & 14.45 & 2.38 \\
\hline $\mathrm{T}_{5}:$ RDF + Foliar application of $1 \%$ Sulphur & 2.99 & 9.01 & 9.79 & 1.73 \\
\hline $\mathrm{T}_{6}: \mathrm{RDF}+$ Foliar application of $1 \%$ each of $\mathrm{CaNO}_{3}, \mathrm{MgNO}_{3}$ and Sulphur & 3.75 & 14.14 & 14.68 & 2.42 \\
\hline $\mathrm{T}_{7}:$ RDF + Foliar application of $\mathrm{ZnSO}_{4} @ 0.2 \%$ & 3.00 & 8.03 & 9.55 & 1.48 \\
\hline $\mathrm{T}_{8}: \mathrm{T}_{6}+$ Foliar application of $\mathrm{ZnSO}_{4} @ 0.2 \%$ & 4.14 & 16.30 & 15.89 & 2.66 \\
\hline SEm \pm & 0.137 & 0.584 & 0.465 & 0.093 \\
\hline $\mathrm{CD}(\mathrm{P}=0.05)$ & 0.42 & 1.77 & 1.41 & 0.28 \\
\hline
\end{tabular}

Table.4 S uptake $\left(\mathrm{kg} \mathrm{ha}^{-1}\right)$ by blackgram at different growth stages as influenced by secondary nutrients and zinc nutrition

\begin{tabular}{|c|c|c|c|c|}
\hline \multirow[t]{3}{*}{ Treatments } & \multicolumn{4}{|c|}{ S uptake (kg ha' $\left.{ }^{-1}\right)$} \\
\hline & \multirow[t]{2}{*}{30 DAS } & \multirow[t]{2}{*}{60 DAS } & \multicolumn{2}{|c|}{ At harvest } \\
\hline & & & Haulm & Seed \\
\hline $\mathrm{T}_{1}$ : Control & 0.61 & 0.91 & 1.13 & 0.41 \\
\hline $\mathrm{T}_{2}$ : Recommended dose of fertilizers (RDF) $\left(20-50-0 \mathrm{~kg} \mathrm{~N}, \mathrm{P}_{2} \mathrm{O}_{5}\right.$ and $\left.\mathrm{K}_{2} \mathrm{O} \mathrm{ha}^{-1}\right)$ & 0.70 & 1.35 & 1.33 & 0.59 \\
\hline $\mathrm{T}_{3}: \mathrm{RDF}+$ Foliar application of $1 \% \mathrm{CaNO}_{3}$ & 0.95 & 2.10 & 2.23 & 1.04 \\
\hline $\mathrm{T}_{4}: \mathrm{RDF}+$ Foliar application of $1 \% \mathrm{MgNO}_{3}$ & 0.92 & 2.43 & 2.23 & 1.15 \\
\hline $\mathrm{T}_{7}: \mathrm{RDF}+$ Foliar application of $\mathrm{ZnSO}_{4} @ 0.2 \%$ & 0.97 & 1.83 & 1.90 & 0.93 \\
\hline $\mathrm{T}_{8}: \mathrm{T}_{6}+$ Foliar application of $\mathrm{ZnSO}_{4} @ 0.2 \%$ & 1.51 & 3.87 & 3.20 & 1.72 \\
\hline SEm \pm & 0.052 & 0.124 & 0.079 & 0.044 \\
\hline $\mathrm{CD}(\mathrm{P}=0.05)$ & 0.16 & 0.38 & 0.24 & 0.13 \\
\hline
\end{tabular}


Table.5 Zn uptake $\left(\mathrm{g} \mathrm{ha}^{-1}\right)$ by blackgram at different growth stages as influenced by secondary nutrients and zinc nutrition

\begin{tabular}{|c|c|c|c|c|}
\hline \multirow[t]{3}{*}{ Treatments } & \multicolumn{4}{|c|}{ Zn uptake $\left(\mathrm{g} \mathrm{ha}^{-1}\right)$} \\
\hline & \multirow[t]{2}{*}{30 DAS } & \multirow[t]{2}{*}{60 DAS } & \multicolumn{2}{|c|}{ At harvest } \\
\hline & & & Haulm & Seed \\
\hline $\mathrm{T}_{1}$ : Control & 19.71 & 28.08 & 22.26 & 18.32 \\
\hline $\mathrm{T}_{2}$ : Recommended dose of fertilizers (RDF) (20-50-0 kg N, $\mathrm{P}_{2} \mathrm{O}_{5}$ and $\left.\mathrm{K}_{2} \mathrm{O} \mathrm{ha}^{-1}\right)$ & 24.00 & 35.70 & 25.36 & 27.64 \\
\hline $\mathrm{T}_{3}: \mathrm{RDF}+$ Foliar application of $1 \% \mathrm{CaNO}_{3}$ & 29.26 & 53.98 & 34.14 & 45.33 \\
\hline $\mathrm{T}_{4}: \mathrm{RDF}+$ Foliar application of $1 \% \mathrm{MgNO}_{3}$ & 41.49 & 67.14 & 35.15 & 52.04 \\
\hline $\mathrm{T}_{5}:$ RDF + Foliar application of $1 \%$ Sulphur & 37.62 & 54.44 & 29.17 & 48.80 \\
\hline $\mathrm{T}_{6}: \mathrm{RDF}+$ Foliar application of $1 \%$ each of $\mathrm{CaNO}_{3}, \mathrm{MgNO}_{3}$ and Sulphur & 55.40 & 96.84 & 44.33 & 75.17 \\
\hline $\mathrm{T}_{7}: \mathrm{RDF}$ + Foliar application of $\mathrm{ZnSO}_{4} @ 0.2 \%$ & 129.53 & 194.32 & 115.64 & 88.01 \\
\hline $\mathrm{T}_{8}: \mathrm{T}_{6}+$ Foliar application of $\mathrm{ZnSO}_{4} @ 0.2 \%$ & 136.12 & 249.25 & 149.29 & 124.69 \\
\hline SEm \pm & 3.243 & 6.492 & 1.985 & 4.709 \\
\hline $\mathrm{CD}(\mathrm{P}=0.05)$ & 9.84 & 19.69 & 6.02 & 14.28 \\
\hline
\end{tabular}

Table.6 Gross returns, net returns and Benefit cost- ratio of blackgram cultivation as influenced by Secondary nutrients and zinc nutrition

\begin{tabular}{|c|c|c|c|}
\hline Treatments & $\begin{array}{l}\text { Gross returns } \\
\left(₹ \mathbf{h a}^{-1}\right)\end{array}$ & $\begin{array}{l}\text { Net returns } \\
\left(₹ \mathrm{ha}^{-1}\right)\end{array}$ & $\begin{array}{l}\text { Benefit-cost } \\
\text { ratio }\end{array}$ \\
\hline $\mathrm{T}_{1}$ : Control & 29464 & 13784 & 1.88 \\
\hline $\mathrm{T}_{2}$ : Recommended dose of fertilizers (RDF) $\left(20-50-0 \mathrm{~kg} \mathrm{~N}, \mathrm{P}_{2} \mathrm{O}_{5}\right.$ and $\left.\mathrm{K}_{2} \mathrm{O} \mathrm{ha}^{-1}\right)$ & 37068 & 18316 & 1.98 \\
\hline $\mathrm{T}_{3}: \mathrm{RDF}+$ Foliar application of $1 \% \mathrm{CaNO}_{3}$ & 59082 & 39030 & 2.95 \\
\hline $\mathrm{T}_{4}: \mathrm{RDF}+$ Foliar application of $1 \% \mathrm{MgNO}_{3}$ & 63142 & 43190 & 3.16 \\
\hline$T_{5}:$ RDF + Foliar application of $1 \%$ Sulphur & 51877 & 30925 & 2.48 \\
\hline $\mathrm{T}_{6}: \mathrm{RDF}+$ Foliar application of $1 \%$ each of $\mathrm{CaNO}_{3}, \mathrm{MgNO}_{3}$ and Sulphur & 68852 & 45400 & 2.94 \\
\hline $\mathrm{T}_{7}:$ RDF + Foliar application of $\mathrm{ZnSO}_{4} @ 0.2 \%$ & 45368 & 26536 & 2.41 \\
\hline $\mathrm{T}_{8}: \mathrm{T}_{6}+$ Foliar application of $\mathrm{ZnSO}_{4} @ 0.2 \%$ & 74484 & 50952 & 3.17 \\
\hline SEm \pm & 2796 & 2796 & 0.17 \\
\hline $\mathrm{CD}(\mathrm{P}=\mathbf{0 . 0 5})$ & 8481 & 8481 & 0.51 \\
\hline
\end{tabular}


Regarding the individual foliar sprays of secondary nutrients and zinc treatments, RDF + foliar application of one per cent sulphur $\left(\mathrm{T}_{5}\right)$ achieved greater values of sulphur uptake at 30 DAS and by haulm at harvest. While at 60 DAS and by seed at harvest, RDF + foliar application of one per cent $\mathrm{MgNO}_{3}\left(\mathrm{~T}_{4}\right)$ treatment recorded higher sulphur uptake. But all the individual secondary nutrient foliar sprays were on par with each other at 30,60 DAS and at harvest.

Higher uptake of sulphur with combination of secondary nutrients and zinc might be due to application of sulphur as well as zinc sulphate and due to higher dry matter accumulation by the crop. Both the synergism and antagonism was possible between sulphur and zinc (Prasad, 2016). While in the present study, positive interaction was observed and this might have contributed to higher uptake in the combination treatment i.e. foliar spray of secondary nutrients along with zinc. Though dry matter accumulation was not considerable in the zinc sulphate foliar spray, sulphur uptake was relatively increased due to the presence of sulphur in the fertilizer. Increased sulphur uptake with foliar spray of sulphur was inferred by Devi and Pillai (2000), Veerabhadrappa and Yeledhalli (2005b) and Choudhary et al., (2014).

\section{Zinc}

The treatment $\mathrm{T}_{6}+$ foliar application of $\mathrm{ZnSO}_{4}$ @ 0.2 per cent $\left(\mathrm{T}_{8}\right)$ recorded significantly higher uptake of zinc at all the crop growth stages. The next best treatment was RDF + foliar application of $\mathrm{ZnSO}_{4} @ 0.2$ per cent $\left(\mathrm{T}_{7}\right)$ which was equally effective with higher treatment at $30 \mathrm{DAS}$. RDF + foliar application of one per cent each of $\mathrm{CaNO}_{3}$, $\mathrm{MgNO}_{3}$ and sulphur $\left(\mathrm{T}_{6}\right)$ treatment also recorded notable zinc uptake at all the stages of crop growth. Regarding individual secondary nutrients foliar sprays, RDF + foliar application of one per cent $\mathrm{MgNO}_{3}\left(\mathrm{~T}_{4}\right)$ treatment recorded higher values (Table 5).

Higher uptake of zinc was found in the treatments that contained zinc foliar spray in its nutrient management practices. Though individual spray of zinc along with RDF recorded comparatively lesser dry matter accumulation than combination treatments, higher zinc uptake was due to its higher zinc concentration. The zinc uptake by seed was greater than the haulm uptake due to the translocation of zinc to the reproductive structures (Puniya et al., 2014). Among the individual secondary nutrient foliar sprays, magnesium foliar spray increased the zinc uptake because of synergism between the two elements (Prasad et al., 2016).

\section{Economics}

Any recommendation to reach the farmers and its adoption depends on the profitability. Such is the importance of economics for the success of any technology.

Among all the treatments, $\mathrm{T}_{6}+$ foliar application of $\mathrm{ZnSO}_{4} @ 0.2$ per cent $\left(\mathrm{T}_{8}\right)$ treatment realized higher gross and net returns and was equally profitable with the treatment $\mathrm{RDF}+$ foliar application of one per cent each of $\mathrm{CaNO}_{3}, \mathrm{MgNO}_{3}$ and sulphur $\left(\mathrm{T}_{6}\right)$.

With respect to individual secondary nutrients and zinc foliar sprays, RDF + foliar application of one per cent $\mathrm{MgNO}_{3}\left(\mathrm{~T}_{4}\right)$ treatment achieved higher gross and net returns and was on par with $\mathrm{T}_{6}+$ foliar application of $\mathrm{ZnSO}_{4} @ 0.2$ per cent $\left(\mathrm{T}_{8}\right)$ treatment in achieving higher net returns.

While, $\mathrm{RDF}+$ foliar application of one per cent $\mathrm{CaNO}_{3} \quad\left(\mathrm{~T}_{3}\right)$ treatment was equally effective with RDF + foliar application of one per cent $\mathrm{MgNO}_{3}\left(\mathrm{~T}_{4}\right)$ treatment in recording higher gross and net returns (Table 6). 
Higher B: C ratio was obtained with $\mathrm{T}_{6}+$ foliar application of $\mathrm{ZnSO}_{4}$ @ 0.2 per cent $\left(\mathrm{T}_{8}\right)$ and was on par with $\mathrm{RDF}+$ foliar application of one per cent $\mathrm{MgNO}_{3}\left(\mathrm{~T}_{4}\right), \mathrm{RDF}$ + foliar application of one per cent $\mathrm{CaNO}_{3}$ $\left(\mathrm{T}_{3}\right)$ and $\mathrm{RDF}+$ foliar application of one per cent each of $\mathrm{CaNO}_{3}, \mathrm{MgNO}_{3}$ and sulphur $\left(\mathrm{T}_{6}\right)$ treatments.

Higher gross and net returns with both the combination treatments $\left(\mathrm{T}_{8}\right.$ and $\left.\mathrm{T}_{6}\right)$ and magnesium foliar spray were due to higher seed yields in the corresponding treatments. Lower B: C ratio in the treatments with combination of secondary nutrients and individual foliar spray of sulphur was due to higher cost of sulphur. Similar results with respect to magnesium were recorded by Yedukondalu et al., (2007). The results of increase in $\mathrm{B}$ : $\mathrm{C}$ ratio with calcium treatment over control was reported by Kundu and Sarkar (2009), zinc treatment over control was revealed by Anitha et al., (2005), Ramaprasad et al., (2011) and Prasanna et al., (2013).

Among all the foliar sprays tested, the treatment with combined application of secondary nutrients and zinc resulted in higher gross returns, net returns and $\mathrm{B}$ : $\mathrm{C}$ ratio. Interestingly, $\mathrm{B}$ : $\mathrm{C}$ ratio of magnesium treatment was also higher due to its lower price. Over all it can be concluded that foliar application of one per cent each of calcium, magnesium, sulphur and 0.2 per cent $\mathrm{ZnSO}_{4}$ at 25 and 45 DAS along with RDF increased the growth, productivity, net returns and nutrient uptake by blackgram

\section{References}

Anitha, S., Sreenivasan, E. and Purushothaman, S. M. 2005. Response of cowpea [Vigna unguiculata (L.) Walp.] to foliar nutrition of zinc and iron in the oxisols of Kerala. Legume Research, 28 (4): 294-296.

Cheng, K. L. and Bray, R.H. 1951. Determination of calcium and magnesium in soil and plant material. Soil Science, 72: 449-458.

Choudhary, A. K., Pooniya, V., Bana, R. S., Kumar, A. and Singh, U. 2014. Mitigating pulse productivity constraints through phosphorus fertilization - A review. Agricultural Reviews, 35 (4): 314-319.

Devi, A. A. and Pillai, R. N. 2000. Effect of foliar application of sulphuric acid on seed yield and nutrient uptake by urdbean. Legume Research, 23 (2): 139140.

Fageria, N. K., Filho, M. P. B., Moreira. A. and Guimaraes. C. M. 2009. Foliar fertilization of crop plants. Journal of Plant Nutrition, 32: 1044-1064.

Fageria, V. D. 2001. Nutrient interactions in crop plants. Journal of Plant Nutrition, 24(8): 1269-1290.

Hafeez, B., Khanif, Y. M. and Saleem, M. 2013. Role of zinc in plant nutrition - A review. American Journal of Experimental Agriculture, 3 (2): 374391.

Howladar, S. M., Osman, A. Sh., Rady, M. M. and Al-Zahrani, H. S. 2014. Magnesium foliar application and phosphorien soil inoculation positively affect Pisum sativum L. plants grown on sandy calcareous soil. World Academy of Science, Engineering and Technology, 8 (5): 436-440.

Kundu, C. and Sarkar, R. K. 2009. Effect of foliar application of potassium nitrate and calcium nitrate on performance of rainfed lowland rice (Oryza sativa). Indian Journal of Agronomy, 54 (4): 428-432.

Meena, S., Malarkodi, M. and Senthilvalavan, P. 2007. Secondary and micronutrients 
for groundnut - A review. Agricultural Reviews, 28 (4): 295-300.

Mobarak, Z. M., Shaaban, M. M., El-Fouly, M. M. and El-Nour, E. A. A. A. 2013. Improving growth and nutrient content of maize and cotton plants through magnesium nitrate foliar fertilization. American Journal of Plant Nutrition and Fertilization Technology, 3 (2): 2232.

Pooniya, V., Choudhary, A. K., Dass, A., Bana, R. S., Rana, K. S., Rana, D. S., Tyagi, V. K. and Puniya, M. M. 2015. Improved crop management practices for sustainable pulse production: An Indian perspective. Indian Journal of Agricultural Sciences, 85 (6): 747-758.

Prasad, R., Shivay, Y. S. and Kumar, D. 2016. Interactions of zinc with other nutrients in soils and plants - A Review. Indian Journal of Fertilisers, 12 (5): 16-26.

Prasanna, K. L., Naidu, S. M. M., Sumathi, V. and Nagamani, C. 2013. Effect of nitrogen and zinc on growth, yield and economics of cluster bean [Cyamopsis tetragonoloba (L.) Taub]. The Andhra Agricultural Journal, 60 (2): 260-263.

Rady, M. M. and Osman, A. Sh. 2010. Possibility of overcoming the adverse conditions for growth of bean plants in sandy calcareous soil by using biophosphorus fertilizer and magnesium foliar applications. Egyptian Journal of Horticulture, 37 (1): 85-101.

Ramaprasad, P. D., Rao, Ch. P. and Srinivasulu, K. 2011. Effect of zinc management on yield, nutrient uptake and economics of kabuli chickpea
(Cicer kabulicem L.). The Andhra Agricultural Journal, 58 (3): 258-261.

Ranade, U. and Malvi. 2011. Interaction of micronutrients with major nutrients with special reference to potassium. Karnataka Journal of Agricultural Sciences, 24 (1): 106-109.

Singh, Y. P. 2004. Role of sulphur and phosphorus in blackgram production. Fertiliser News, 49 (2): 33-36.

Tandon, H. L. S. 1998. Methods of analysis of soils, plants, water and fertilizers. Fertilizer Development and Consultation Organization, 31: 9-16.

Veerabhadrappa, B. H. and Yeledhalli, N. A. 2005a. Effect of soil and foliar application of nutrients on growth and yield of groundnut. Karnataka Journal of Agricultural Sciences, 18 (3):814816.

Veerabhadrappa, B. H. and Yeledhalli, N. A. 2005b. Effect of soil and foliar nutrition on uptake of selected nutrients by different plant parts and nutrient ratios in groundnut. Karnataka Journal of Agricultural Sciences, 18 (4): 936-939.

Yedukondalu, V., Chetti, M. B., Uppar, D. S. and Hiremanth, S. M. 2007. Influence of magnesium on growth, yield and quality of soybean. Annals of Plant Physiology, 21 (2): 150-153.

Zafar, S., Nasri, M., Moghadam, H. R. T. and Zahedi, H. 2014. Effect of zinc and sulphur foliar applications on physiological characteristics of sunflower (Helianthus annuus L.) under water deficit stress. International Journal of Biosciences, 5 (12): 87-96.

\section{How to cite this article:}

Jeevana Lakshmi, E., P.V. Ramesh Babu, G. Prabhakara Reddy and Kavitha, P. 2018. Economics and Nutrient Uptake by Blackgram as Influenced by Secondary Nutrients and Zinc Nutrition. Int.J.Curr.Microbiol.App.Sci. 7(10): 2360-2369.

doi: https://doi.org/10.20546/ijcmas.2018.710.273 